\title{
COVID-19 and Air Pollution in Indian Cities: World's Most Polluted Cities
}

\author{
Sonal Kumari, Anita Lakhani, K. Maharaj Kumari* \\ Department of Chemistry, Faculty of Science, Dayalbagh Educational Institute, Dayalbagh, Agra 282110, India
}

\begin{abstract}
In the present study, pollutants levels from $24^{\text {th }}$ March-31 $31^{\text {st }}$ May in 2020 were compared with the same time period in 2019 to estimate the impact of lockdown on air pollutants levels in 39 different cities of India (including 10 Indian cities considered among the world's 20 most polluted cities). Data for air pollutants was obtained from the Central Pollution Control Board (CPCB) which was statistically analyzed. Tropospheric $\mathrm{NO}_{2}$ column retrieved from Ozone Monitoring Instrument (OMI) were compared between 2019 and 2020 to compare the $\mathrm{NO}_{2}$ levels. Impact of lockdown measures on Ghaziabad which is the world's most polluted city and Patiala which showed maximum reduction during the lockdown period in the present study was studied in detail. After the implementation of lockdown measures, air pollution decreased but with substantial variation among pollutants. The most significant reduction was observed for nitrogen dioxide $\left(\mathrm{NO}_{2}\right)(3-$ $79 \%)$ and carbon monoxide $(\mathrm{CO})(2-61 \%)$, pollutants which are mainly related to traffic emissions. Ozone $\left(\mathrm{O}_{3}\right)$ showed a mixed trend with increasing levels at some cities which may be attributed to lower titration of $\mathrm{O}_{3}$ by NO. Maximum reduction observed in $\mathrm{PM}_{10}$ and $\mathrm{PM}_{2.5}$ was 58 and 57\%, respectively during the lockdown period in 2020 as compared to the previous year. Air quality of the cities also improved in 2020. During the lockdown period in 2020, AQI of only $15 \%$ of cities was in the 'Unhealthy' category (151-200) while in 2019, 56\% of cities were in the 'Unhealthy' category. In Ghaziabad and Patiala all the pollutants showed significant reduction after lockdown implementation except $\mathrm{O}_{3}$. Diurnal patterns of $\mathrm{PM}_{10}$, $\mathrm{PM}_{2.5}$, $\mathrm{CO}$ and $\mathrm{NO}_{2}$ showed lower values during lockdown period in 2020 with less distinct bimodal patterns as compared to 2019. The present study provides evidence that widespread implementation of air pollution measures can result in immediate air quality benefits.
\end{abstract}

Keywords: Lockdown; World's most polluted cities; India; Air pollution reduction; AQI.

\section{INTRODUCTION}

In late December 2019, novel infectious coronavirus disease (COVID-19) was identified in Wuhan, China which was later on confirmed to be transmitted human to human through respiratory droplets (WHO, 2020). On $30^{\text {th }}$ January, the first confirmed case of COVID-19 in India was found. As of $23^{\text {rd }}$ March 2020, the number of COVID-19 cases increased to 499 in India (https://www.worldometers.info/coronavirus/ country/india/) which was still very less than many other countries like US, Italy and China. India being the world's second most populated country with many densely populated cities had chances of spread of the virus at an accelerating rate. To prevent the spread of the COVID-19, the government of India imposed nationwide lockdown from $24^{\text {th }}$ March to $31^{\text {st }}$ May. As a result, all non-essential services including schools, colleges, religious worship places, government offices,

\footnotetext{
${ }^{*}$ Corresponding author.

Tel.: 91-562-280154; Fax: 91-562-2801226

E-mail address: maharajkumari.k@rediffmail.com
}

modes of transport (trains, flights and cabs), public utilities and industrial activities were closed. Citizens were advised to remain at home and to maintain social distancing.

On the basis of annual average of $\mathrm{PM}_{2.5}$ in 2019 IQAir identified most polluted cities in the world with 13 Indian cities among the top 20 polluted cities (IQAir Report, 2019) (Table 1). Only $1 \%$ of the Indian population is exposed to less than the global WHO guideline level of annual mean $\mathrm{PM}_{2.5}\left(10 \mu \mathrm{g} \mathrm{m}^{-3}\right)$ (IEA, 2016). Major sources of $\mathrm{PM}_{2.5}$ in India are anthropogenic activities like fossil fuel combustion, transportation, industrial emission (Venkataraman et al., 2018). High levels of pollutants impose significant health issues (Chowdhury and Dey, 2016). In 2017, 1.24 million deaths in India (12.5\% of the total deaths) were attributable to air pollution (Balakrishnan et al., 2019). Therefore, efficient monitoring of air quality at the city level would help in understanding the major contributing sources and the policy making for achieving better air quality. With the implementation of lockdown measures in India, a sudden break on all anthropogenic activities (mainly transportation and industrial activities) improved the air quality. Delhi, the world's most polluted capital city witnessed blue sky with about $49 \%$ reduction in air quality index (AQI) during the 
Table 1. $\mathrm{PM}_{2.5}$ annual average in 2019 reported by IQAir and AQI of cities and name and concentration of AQI species during $24^{\text {th }}$ March-31 ${ }^{\text {st }}$ May 2019-2020 in 39 cities. 24-h average $\mathrm{PM}_{2.5}\left(\mu \mathrm{g} \mathrm{m}^{-3}\right), 8$-h average $\mathrm{O}_{3}(\mathrm{ppb}), 1-\mathrm{h}$ average $\mathrm{NO}_{2}$ (ppb) levels.

\begin{tabular}{|c|c|c|c|c|c|c|c|c|}
\hline State & $\begin{array}{l}\text { City (Rank } \\
\text { according to } \\
\text { IQAir Report } \\
\text { 2019) }\end{array}$ & $\begin{array}{l}\text { Latitude } \\
\left({ }^{\circ} \mathrm{N}\right)\end{array}$ & $\begin{array}{l}\text { Longitude } \\
\left({ }^{\circ} \mathrm{E}\right)\end{array}$ & $\begin{array}{l}\mathrm{PM}_{2.5} \\
\text { Annual } \\
\text { Average } \\
\text { in } 2019 \\
\left(\mu \mathrm{g} \mathrm{m}^{-3}\right)\end{array}$ & $\begin{array}{l}\text { AQI } \\
\left(24^{\text {th }} \text { Mar }\right. \\
-31^{\text {st }} \text { May } \\
2019)\end{array}$ & $\begin{array}{l}\text { AQI } \\
\text { Specie and } \\
\text { its mean } \\
\text { level } \\
(2019)\end{array}$ & $\begin{array}{l}\text { AQI } \\
\left(24^{\text {th }} \text { Mar- }\right. \\
31^{\text {st }} \text { May } \\
2020)\end{array}$ & $\begin{array}{l}\text { AQI } \\
\text { Specie } \\
\text { and its } \\
\text { mean level } \\
(2020)\end{array}$ \\
\hline \multirow[t]{3}{*}{ Punjab } & Amritsar (147) & 31.62 & 74.87 & 47.2 & 144 & $\mathrm{PM}_{2.5}(53)$ & 80 & $\mathrm{PM}_{2.5}(26)$ \\
\hline & Ludhiana (127) & 30.9 & 75.80 & 49.3 & 137 & $\mathrm{PM}_{2.5}(50)$ & 110 & $\mathrm{NO}_{2}(146)$ \\
\hline & Patiala (310) & 30.34 & 76.37 & 35.2 & 152 & $\mathrm{PM}_{2.5}(57)$ & 78 & $\mathrm{PM}_{2.5}(25)$ \\
\hline \multirow[t]{4}{*}{ Rajasthan } & Udaipur & 24.58 & 73.70 & - & 99 & $\mathrm{PM}_{2.5}(35)$ & 87 & $\mathrm{PM}_{2.5}(29)$ \\
\hline & Bhiwadi (20) & 28.20 & 76.83 & 83.4 & 178 & $\mathrm{PM}_{2.5}(107)$ & 147 & $\mathrm{PM}_{2.5}(54)$ \\
\hline & Jaipur (120) & 26.90 & 75.83 & 50.5 & 122 & $\mathrm{PM}_{2.5}(44)$ & 84 & $\mathrm{O}_{3}(65)$ \\
\hline & Jodhpur (29) & 26.29 & 73.03 & 77.2 & 177 & $\mathrm{PM}_{2.5}(106)$ & 151 & $\mathrm{PM}_{2.5}(56)$ \\
\hline \multirow{4}{*}{ Haryana } & Gurugram (7) & 28.42 & 77.15 & 93.1 & 164 & $\mathrm{PM}_{2.5}(80)$ & 124 & $\mathrm{PM}_{2.5}(45)$ \\
\hline & Jind (17) & 29.32 & 76.30 & 85.4 & 158 & $\mathrm{PM}_{2.5}(70)$ & 126 & $\mathrm{O}_{3}(78)$ \\
\hline & Faridabad (18) & 28.41 & 77.32 & 85 & 190 & $\mathrm{O}_{3}(101)$ & 164 & $\mathrm{O}_{3}(91)$ \\
\hline & Rohtak (63) & 28.87 & 76.62 & 59.7 & 166 & $\mathrm{PM}_{2.5}(85)$ & 127 & $\mathrm{PM}_{2.5}(46)$ \\
\hline Delhi & Delhi (5) & 28.61 & 76.98 & 98.6 & 166 & $\mathrm{O}_{3}(92)$ & 137 & $\mathrm{PM}_{2.5}(51)$ \\
\hline Assam & Guwahati & 26.18 & 91.78 & - & 127 & $\mathrm{PM}_{2.5}(46)$ & 127 & $\mathrm{PM}_{2.5}(46)$ \\
\hline \multirow[t]{2}{*}{ Madhya Pradesh } & Bhopal (174) & 23.22 & 77.19 & 44.6 & 168 & $\mathrm{PM}_{2.5}(89)$ & 115 & $\mathrm{O}_{3}(75)$ \\
\hline & Ujjain (187) & 23.18 & 75.77 & 43.4 & 151 & $\mathrm{O}_{3}(86)$ & 105 & $\mathrm{PM}_{2.5}(37)$ \\
\hline \multirow[t]{8}{*}{ Uttar Pradesh } & Agra (80) & 27.19 & 78.00 & 57.2 & 158 & $\mathrm{PM}_{2.5}(69)$ & 132 & $\mathrm{PM}_{2.5}(48)$ \\
\hline & Ghaziabad (1) & 28.66 & 77.37 & 110.2 & 172 & $\mathrm{PM}_{2.5}(97)$ & 147 & $\mathrm{O}_{3}(84)$ \\
\hline & Noida (6) & 28.63 & 77.36 & 97.7 & 177 & $\mathrm{O}_{3}(96)$ & 129 & $\mathrm{PM}_{2.5}(47)$ \\
\hline & Bulandshahr (13) & 28.41 & 77.83 & 89.4 & 166 & $\mathrm{O}_{3}(92)$ & 161 & $\mathrm{O}_{3}(90)$ \\
\hline & Kanpur (132) & 26.47 & 80.32 & 48.5 & 156 & $\mathrm{PM}_{2.5}(66)$ & 129 & $\mathrm{PM}_{2.5}(47)$ \\
\hline & Lucknow (11) & 26.85 & 80.95 & 90.3 & 161 & $\mathrm{PM}_{2.5}(75)$ & 110 & $\mathrm{PM}_{2.5}(39)$ \\
\hline & Greater Noida (9) & 28.48 & 77.48 & 91.3 & 169 & $\mathrm{O}_{3}(93)$ & 136 & $\mathrm{O}_{3}(81)$ \\
\hline & Varanasi & 25.32 & 82.97 & - & 192 & $\mathrm{O}_{3}(102)$ & 159 & $\mathrm{O}_{3}(89)$ \\
\hline Telangana & Hyderabad (249) & 17.46 & 78.33 & 39 & 99 & $\mathrm{PM}_{2.5}(35)$ & 74 & $\mathrm{PM}_{2.5}(23)$ \\
\hline \multirow[t]{2}{*}{ Andra Pradesh } & Tirupati (560) & 13.63 & 79.42 & 26.4 & 72 & $\mathrm{PM}_{2.5}(22)$ & 68 & $\mathrm{PM}_{2.5}(20)$ \\
\hline & Visakhapatnam (180) & 17.69 & 83.22 & 44 & 97 & $\mathrm{PM}_{2.5}(34)$ & 66 & $\mathrm{PM}_{2.5}(19)$ \\
\hline Gujarat & Ahmedabad (69) & 22.99 & 72.60 & 59 & 162 & $\mathrm{PM}_{2.5}(76)$ & 115 & $\mathrm{O}_{3}(75)$ \\
\hline \multirow[t]{3}{*}{ Maharastra } & Mumbai (169) & 19.06 & 72.83 & 45.3 & 68 & $\mathrm{PM}_{2.5}(20)$ & 114 & $\mathrm{NO}_{2}(172)$ \\
\hline & Nagpur (146) & 21.14 & 79.10 & 47.2 & 129 & $\mathrm{O}_{3}(79)$ & 100 & $\mathrm{NO}_{2}(100)$ \\
\hline & Pune (299) & 18.49 & 73.82 & 35.7 & 142 & $\mathrm{PM}_{2.5}(52)$ & 84 & $\mathrm{PM}_{2.5}(28)$ \\
\hline Tamil Nadu & Chennai (320) & 13.18 & 80.27 & 34.6 & 137 & $\mathrm{PM}_{2.5}(50)$ & 87 & $\mathrm{PM}_{2.5}(29)$ \\
\hline Kerela & $\begin{array}{l}\text { Thiruvananthapuram } \\
\text { (496) }\end{array}$ & 8.51 & 76.95 & 27.9 & 80 & $\mathrm{PM}_{2.5}(26)$ & 66 & $\mathrm{PM}_{2.5}(19)$ \\
\hline Jharkhand & Jorapokhar & 23.71 & 86.41 & - & 150 & $\mathrm{O}_{3}(85)$ & 147 & $\mathrm{O}_{3}(84)$ \\
\hline \multirow[t]{2}{*}{ Bihar } & Gaya (65) & 24.79 & 85.00 & 59.4 & 155 & $\mathrm{PM}_{2.5}(64)$ & 154 & $\mathrm{O}_{3}(87)$ \\
\hline & Patna (22) & 25.59 & 85.14 & 82.1 & 152 & $\mathrm{PM}_{2.5}(57)$ & 156 & $\mathrm{PM}_{2.5}(66)$ \\
\hline \multirow[t]{2}{*}{ West Bengal } & Howrah (91) & 22.57 & 88.30 & 55.9 & 122 & $\mathrm{PM}_{2.5}(44)$ & 72 & $\mathrm{PM}_{2.5}(22)$ \\
\hline & Kolkata (61) & 22.54 & 88.34 & 59.8 & 105 & $\mathrm{PM}_{2.5}(37)$ & 147 & $\mathrm{O}_{3}(84)$ \\
\hline \multirow[t]{2}{*}{ Karnataka } & Bengaluru (361) & 12.92 & 77.61 & 32.6 & 153 & $\mathrm{PM}_{2.5}(60)$ & 91 & $\mathrm{NO}_{2}(92)$ \\
\hline & Kalaburagi & 17.32 & 76.82 & - & 115 & $\mathrm{PM}_{2.5}(41)$ & 97 & $\mathrm{PM}_{2.5}(34)$ \\
\hline
\end{tabular}

lockdown period (https://www.thehindu.com/news/cities/De lhi/coronavirus-lockdown-lifts-delhis-march-air-quality-to5-year-high/article31252221.ece).

Recent studies reported on short term exposure to air pollution and COVID-19 infection have found significant positive association of air pollutants with COVID-19 confirmed cases (Suhaimi et al., 2020; Zhu et al., 2020). Suhaimi et al. (2020) found significant positive association between COVID-19 cases and $\mathrm{PM}_{10}, \mathrm{PM}_{2.5}, \mathrm{CO}, \mathrm{NO}_{2}$ and
$\mathrm{SO}_{2}$ pollutants in Malaysia however, Zhu et al. (2020) observed positive association between COVID-19 cases and $\mathrm{PM}_{10}, \mathrm{PM}_{2.5}, \mathrm{NO}_{2}$ and $\mathrm{O}_{3}$ pollutants in China. Similar studies reported in China, Singapore, New York, Norway, Italy, United States, Spain, Turkey and Indonesia have analyzed the association between climate indicators (temperature, rainfall, humidity, air quality) and COVID-19 and found a significant association between them (Bashir et al., 2020; Gupta et al., 2020; Méndez-Arriaga, 2020; Menebo, 2020; 
Pani et al., 2020; Sahin, 2020; Tobias et al., 2020; Tosepu et al., 2020; Xu et al., 2020; Yao et al., 2020). Temperature which is considered as an important parameter in development, prevention and control of an epidemic showed different correlation in different countries (Tobías and Molina, 2020). A significant positive correlation of COVID-19 cases with temperature is reported over Singapore, New York, Norway, Turkey and Indonesia highlighting the importance of temperature in COVID-19 epidemic whereas a negative correlation is reported over Mexico while no correlation between COVID-19 cases and temperature is observed in China.

Some studies have been reported in India assessing the impact of COVID-19 lockdown on air quality but for limited number of cities and for short time period (Chauhan and Singh, 2020 (2 cities, Dec 2019-March 2020); Jain and Sharma, 2020 (5 cities, 10 ${ }^{\text {th }}$ March- $6^{\text {th }}$ April 2019-2020); Kotnala et al., 2020 (1 city, January-March 2020); Kumar, 2020 (6 cities, March-May 2020); Kumar et al., 2020 (5 cities, March-April 2015-2020); Mahato et al., 2020 (1 city, $3^{\text {rd }}$ March-14 ${ }^{\text {th }}$ April 2020); Navinya et al., 2020 (17 cities, $1^{\text {st }}$ February-3 ${ }^{\text {rd }}$ May 2019-2020); Sharma et al., 2020 (22 cities, 16 ${ }^{\text {th }}$ March-14 ${ }^{\text {th }}$ April 2017-2020); Shehzad et al., 2020 ( 2 cities, $1^{\text {st }}$ January-20 ${ }^{\text {th }}$ April 2019-2020); Singh and Chauhan, 2020 (5 cities, March 2019-2020); Srivastava et

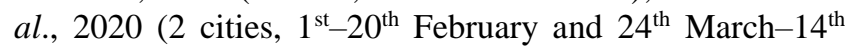
April 2020)). The present study was planned to describe the changes in air pollutants levels during the complete lockdown period ( $24^{\text {th }}$ March-31 ${ }^{\text {st }}$ May) in 39 different cities of India (including 10 Indian cities considered among the world's 20 most polluted cities) by using ground-based and satellite observations.

\section{METHODOLOGY}

\section{Data Sources}

Data for particulate matter $\mathrm{PM}_{10}$ (particulate matter with diameter $\leq 10 \mu \mathrm{m}), \mathrm{PM}_{2.5}$ (particulate matter with diameter $\leq 2.5 \mu \mathrm{m})$, nitrogen dioxide $\left(\mathrm{NO}_{2}\right)$, ozone $\left(\mathrm{O}_{3}\right)$ sulfur dioxide $\left(\mathrm{SO}_{2}\right)$ and carbon monoxide $(\mathrm{CO})$ monitored by Central Pollution Control Board (CPCB) have been analyzed from $24^{\text {th }}$ March $-31^{\text {st }}$ May in 2020 and compared with the same time period in 2019 for 39 cities of India. For Ghaziabad and Patiala a comparison of before ( $1^{\text {st }}$ February-23 $3^{\text {rd }}$ March) and during (24 $4^{\text {th }}$ March-31 ${ }^{\text {st }}$ May) lockdown period in 2019 and 2020 is done. Ten India cities (Ghaziabad (rank 1), Delhi (5), Noida (6), Gurugram (7), Greater Noida (9), Lucknow (11), Bulandshahr (13), Jind (17), Faridabad (18), Bhiwadi (20)) considered in the world's 20 most polluted cities and 29 other Indian cities were analyzed (IQAir Report, 2019). Detailed information about these air quality monitoring stations is given in Table 1.

Mean concentrations of the pollutants for the lockdown period ( $24^{\text {th }}$ March-31 $1^{\text {st }}$ May) in 2019 and 2020 were calculated to assess the variation between both periods having similar meteorology. Independent samples t-test between the mean concentration of all pollutants in 2019 and 2020 at 0.05 significance level was carried out using Statistical Package for Social Sciences (SPSS) software. Most of the cities showed statistical significant difference.

\section{Air Quality Index (AQI)}

Air Quality Index (AQI) is a numerical index used to indicate the air quality of a region. AQI ranges in value from 0-500 with greater AQI value suggesting deteriorated air quality and lower AQI $(<100)$ indicating satisfactory air quality in a region. In the present study, AQI values were derived from $24 \mathrm{~h}$ average $\mathrm{PM}_{10}$ and $\mathrm{PM}_{2.5}, 8 \mathrm{~h}$ average $\mathrm{CO}$ and $\mathrm{O}_{3}, 1 \mathrm{~h}$ average $\mathrm{NO}_{2}$ and $\mathrm{SO}_{2}$ levels during lockdown period in 2019 and 2020 using the U.S.EPA standard formula (U.S. EPA, 1999; Kumar and Goyal, 2011). The overall AQI considered for a city was the maximum AQI observed for that city.

\section{Tropospheric $\mathrm{NO}_{2}$ Column}

Ozone Monitoring Instrument (OMI) daily tropospheric nitrogen dioxide column (OMNO2d version 3$)$ at $0.25^{\circ} \times$ $0.25^{\circ}$ resolution is used in the study. OMI onboard Aura satellite detects the backscattered solar radiation (wavelength range of $270-500 \mathrm{~nm}$ ) from the Earth and its atmosphere with a spatial resolution of $13 \times 24 \mathrm{~km}$ (Krotkov et al., 2017).

\section{RESULTS AND DISCUSSION}

\section{AQI Values in Different Cities during the Lockdown Period}

AQI values were determined for the lockdown period in 2019 and 2020 (24 $4^{\text {th }}$ March-31 ${ }^{\text {st }}$ May) (Fig. 1). In 2019, 56\% of cities were in the 'Unhealthy' category (151-200) and only 16 and $28 \%$ cities lied in the 'Moderate' (51-100) and the 'Unhealthy for sensitive group' category (101-150) (Table 1). In 2020, air quality of most of the cities improved with AQI of $36 \%$ of cities lying under the 'Moderate' category and $49 \%$ of cities in the 'Unhealthy for sensitive group' category. The largest drop in AQI values was observed in Patiala (AQI improved by 74). A relatively higher number of cities in Indo-Gangetic Plain showed lower AQI than cities in other regions of India. Among the 10 most polluted Indian cities AQI in 7 cities reduced to 101-150 range from 151-200 range. This suggests that air quality has improved significantly during the lockdown period in 2020. During $2019 \mathrm{PM}_{2.5}$ was the dominant pollutant in most of the cities (30 cities), however with reduction in AQI in 2020 the dominant species shifted to $\mathrm{O}_{3}$ and $\mathrm{NO}_{2}$ in some of the cities. For cities lying in the central region (Bhopal, Ahmedabad, Gaya, Kolkata, Jaipur, Ghaziabad and Jind) the dominant pollutant shifted to $\mathrm{O}_{3}$ however in some cities (Mumbai, Ludhiana, Bengaluru, Nagpur) it shifted to $\mathrm{NO}_{2}$. In 2019 dominance of $\mathrm{PM}_{2.5}$ in most of the cities suggests influence on air quality by anthropogenic activities such as fossil fuel combustion in road transport, industries and power generation. With reduction in $\mathrm{PM}_{2.5}$ levels during lockdown period in 2020 the emergence of $\mathrm{O}_{3}$ as the dominant pollutant suggests influence on air quality by secondary pollutants in some of the cities.

\section{Variation in Pollutants Levels during the Lockdown Period in 2019 and 2020}

Further, average concentrations of pollutants in all 39 cities 

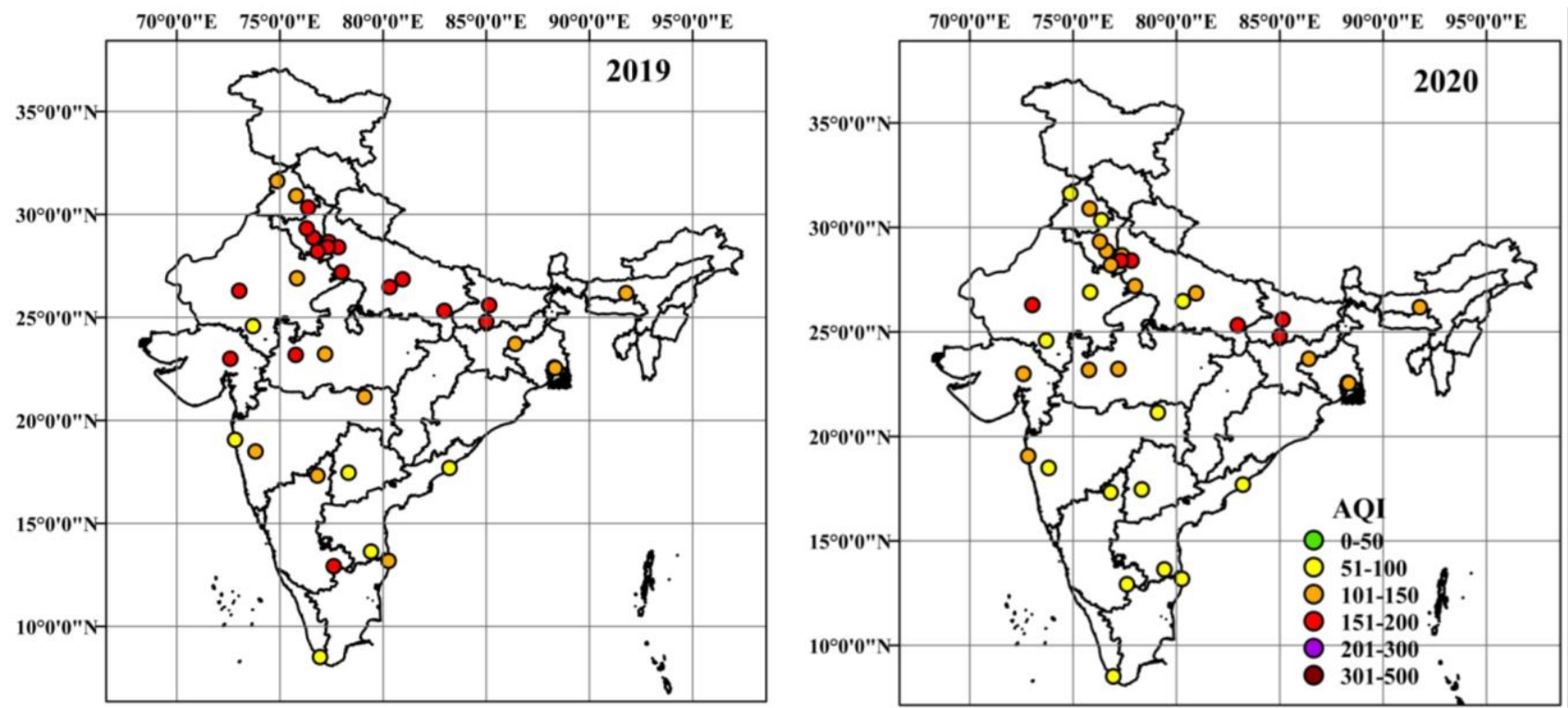

Fig. 1. AQI of 39 cities of India during lockdown period $\left(24^{\text {th }}\right.$ March-31 ${ }^{\text {st }}$ May) in 2019 and 2020.

were compared during the lockdown period in 2019 and 2020 to determine the impact of the lockdown measures on air pollution levels (Fig. 2). Statistically significant differences in pollutants mean levels during the lockdown period in 2019 and 2020 were observed at 0.05 significance level.

During the lockdown period in 2020, all cities showed drop in $\mathrm{PM}_{10}$ levels (except Guwahati and Jorapokhar) with an overall reduction of $44 \%$ as compared to 2019. $\mathrm{PM}_{10}$ levels decreased by $8 \%$ (Kalaburagi) to $58 \%$ (Patiala) in 2020 as compared to 2019. Among the 10 most polluted cities of India, Gurugram showed maximum reduction in $\mathrm{PM}_{10}$ levels (56\%). Similar to $\mathrm{PM}_{10}, \mathrm{PM}_{2.5}$ levels also reduced during the lockdown period in 2020. Average $\mathrm{PM}_{2.5}$ levels over all the cities decreased from 63.6 to $39.6 \mu \mathrm{g} \mathrm{m}^{-3}$ (38\% reduction). $\mathrm{PM}_{2.5}$ levels showed reduction in all cities ranging from $1 \%$ (Guwahati) to $57 \%$ (Patiala) except at Mumbai and Patna. Top 10 most polluted cities showed reduction in the range 33 to $51 \%$. Higher reduction observed in $\mathrm{PM}_{10}$ levels than $\mathrm{PM}_{2.5}$ can be due to the greater contribution of $\mathrm{PM}_{10}$ from anthropogenic activities (Klimont et al., 2017). In China, a reduction by $20-30 \%$ in $\mathrm{PM}_{2.5}$ levels during February 2020 (lockdown period) in comparison to monthly averages of February in 2017-2019 based on satellite observation was found (CAMS, 2020). Cities situated in the northern region (mainly in Uttar Pradesh) showed higher reduction in $\mathrm{PM}_{10}$ and $\mathrm{PM}_{2.5}$ levels. Uttar Pradesh contributes the highest share in $\mathrm{PM}_{2.5}$ emission as compared to other states of India (Purohit et al., 2019). The number of cities with daily $24 \mathrm{~h}$ mean $\mathrm{PM}_{10}$ and $\mathrm{PM}_{2.5}$ concentrations exceeding the National Ambient Air Quality Standards (NAAQS: $\mathrm{PM}_{10}>100 \mu \mathrm{g} \mathrm{m}^{-3}$ and $\mathrm{PM}_{2.5}$ $>60 \mu \mathrm{g} \mathrm{m}^{-3}$ ) during the lockdown period in 2019 and 2020 were compared (NAAQS, 2009). 96\% of cities in 2019 exceeded the NAAQS limit for $\mathrm{PM}_{10}$ while in 2020 , only $75 \%$ of cities violated the limit. Similarly, $\mathrm{PM}_{2.5}$ levels in 2019 were exceeded by $80 \%$ of cities however, in 2020 , only $53 \%$ of cities exceeded the limit during the lockdown period.

$\mathrm{NO}_{2}$ is a primary pollutant which is emitted mainly from vehicular emission and industrial activities (Sahu et al., 2012). The number of registered vehicles in India in 2016 was around 230 million which has increased 4 times from 2001 (http://mospi.nic.in/statistical-year-book-india/2018/189). This shows the dramatic increase in the vehicular population in India. With the implementation of lockdown measures in India, all transportation facilities and industrial activities were stopped immediately. As these activities have a direct effect on $\mathrm{NO}_{2}$ levels, an immediate reduction in $\mathrm{NO}_{2}$ is observed. During the lockdown period in 2020, $\mathrm{NO}_{2}$ reduced by $3 \%$ (Hyderabad) to $79 \%$ (Patiala) in India (overall mean reduction 42\%) (except at Agra, Jorapokhar, Ludhiana, Noida, Thiruvananthapuram and Patna). Similarly, reduction in $\mathrm{NO}_{2}$ levels in Wuhan $\left(22.8 \mu \mathrm{g} \mathrm{m}^{-3}\right)$ and China $\left(12.9 \mu \mathrm{g} \mathrm{m}^{-3}\right)$ was also observed during the lockdown period (ZambranoMonserrate et al., 2020). To further substantiate the influence of lockdown measures on $\mathrm{NO}_{2}$ levels, satellite-retrieved tropospheric $\mathrm{NO}_{2}$ column was also analyzed for the lockdown period in 2019 and 2020 (Fig. 3) and a reduction in $\mathrm{NO}_{2}$ levels during 2020 was found. Among 39 cities considered in the present study, maximum reduction by $54 \%$ in tropospheric $\mathrm{NO}_{2}$ column over Patiala city (similar to ground observation) was observed during the lockdown period in 2020 as compared to 2019. NASA (National Aeronautics and Space Administration) and ESA (European Space Agency) using satellite observations have also reported reduction in $\mathrm{NO}_{2}$ emissions in Wuhan, Spain, Italy and USA by up to $30 \%$ during the lockdown period (Muhammad et al., 2020).

Tropospheric $\mathrm{O}_{3}$ is a secondary air pollutant which is photo-chemically formed from its precursors $\mathrm{CO}$, nitrogen oxides and volatile organic compounds (Kumari et al., 2018). $\mathrm{O}_{3}$ levels at a site not only depend on precursor's concentration but also on meteorological parameters. Sharma et al. (2020) found that meteorological parameters in India during the lockdown period in 2020 were similar to the analysis period in the previous years. This suggests that $\mathrm{O}_{3}$ levels were mainly influenced by precursor's concentration during the 
lockdown period in 2020. $\mathrm{O}_{3}$ levels in most of the cities lying in the northern and central India were observed to be increasing (1-27.7 ppb range) during the lockdown period in 2020. This may be attributed by a decrease in $\mathrm{NO}_{\mathrm{x}}$ levels in VOCs sensitive environment as cities in the northern and
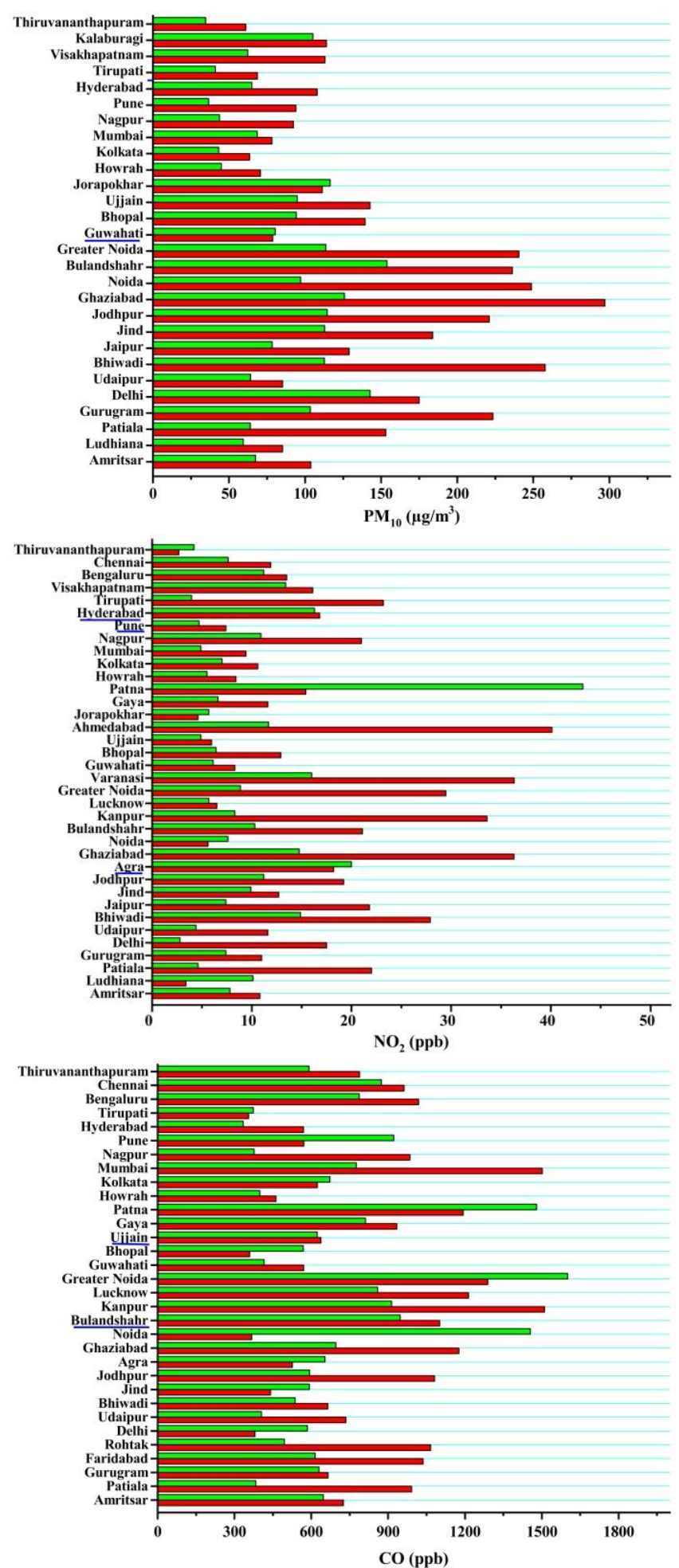

central regions are VOC-sensitive (Sharma et al., 2016). The other reasons may be reduction in $\mathrm{NO}$ titration of $\mathrm{O}_{3}$ and reduced particulate matter levels as observed by similar study during the lockdown period (Tobias et al., 2020). However, other cities showed reduction in $\mathrm{O}_{3}$ levels during the lockdown
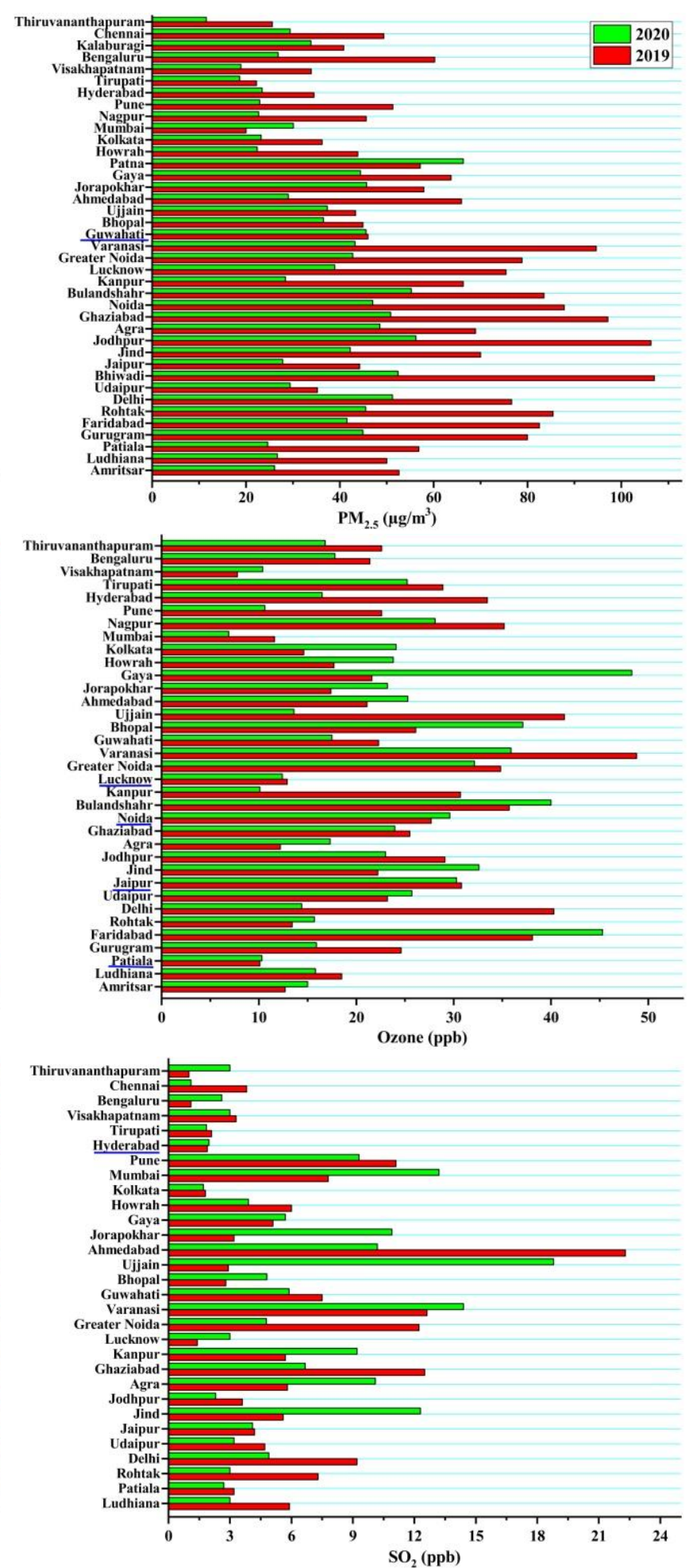

Fig. 2. Mean concentrations of $\mathrm{PM}_{10}, \mathrm{PM}_{2.5}, \mathrm{NO}_{2}, \mathrm{O}_{3}, \mathrm{CO}$ and $\mathrm{SO}_{2}$ during $24^{\text {th }}$ March-31 ${ }^{\text {st }}$ May in 2019 and 2020 (lockdown period) (cities not showing statistical difference in mean values between 2019 and 2020 at 0.05 significance level are underlined). 
NO2 Tropospheric Column (30\% Cloud Screened) in 2019
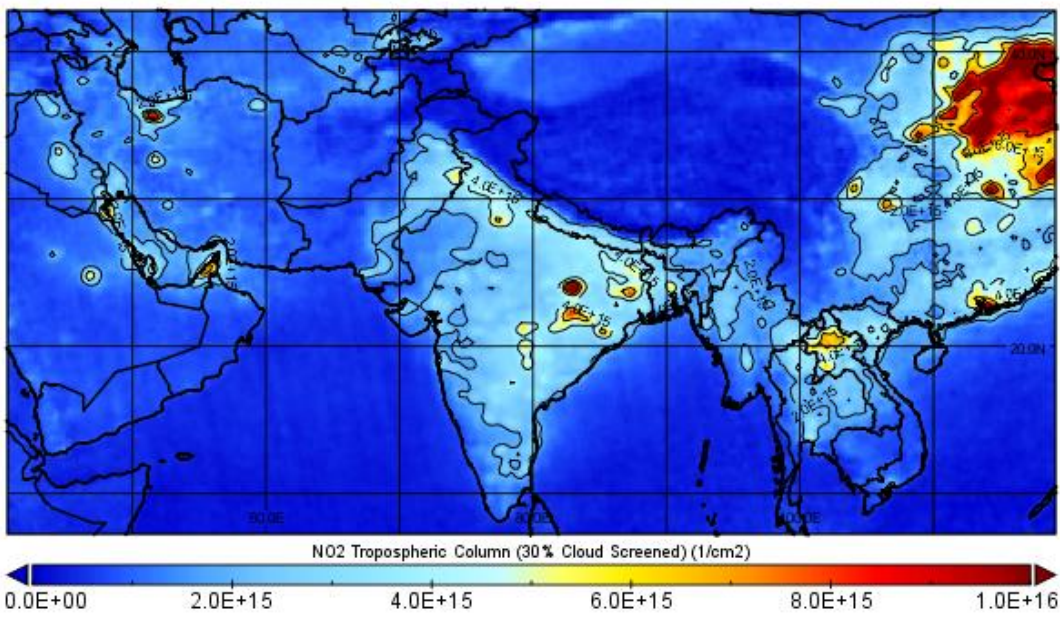

NO2 Tropospheric Column (30\% Cloud Screened) in 2020

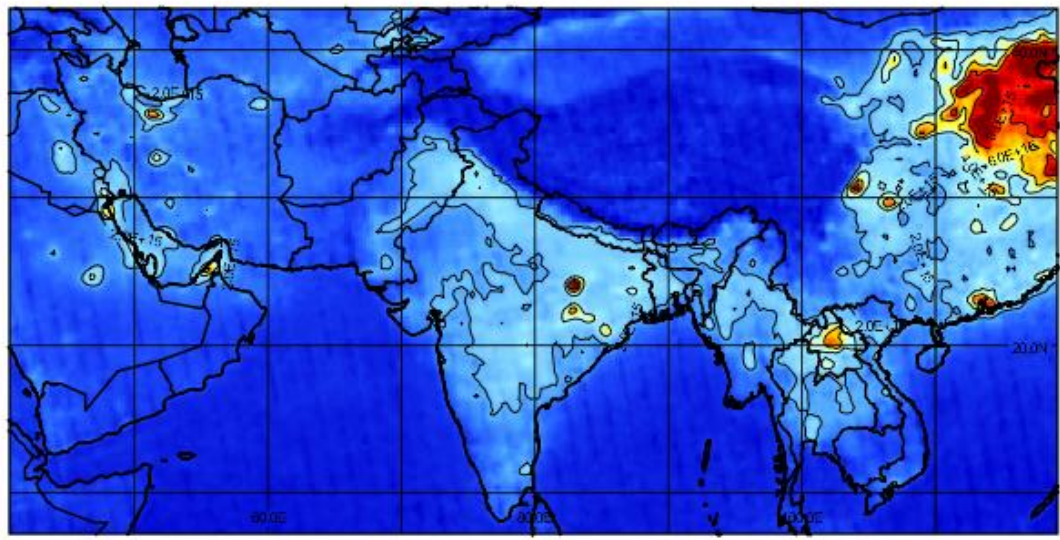

N02 Tropospheric Column (30\% Cloud Screened) (1/cm2)

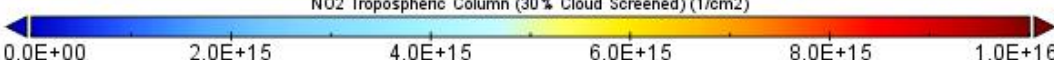

Fig. 3. Tropospheric $\mathrm{NO}_{2}$ column over India during lockdown period in 2019 and 2020 .

period (range 2 to $89 \%$ ). Among the 10 most polluted cities, four cities showed higher levels in 2020 as compared to 2019 with highest increase observed at Jind (47\%).

$\mathrm{CO}$ is one of the major air pollutants released from biomass burning and incomplete combustion of fossil fuels (Hollaway et al., 2000). Similar to $\mathrm{NO}_{2}, \mathrm{CO}$ levels also decreased (range 2-61\%; overall mean reduction $28 \%$ ) during the lockdown period in 2020. However, in some of the cities (Delhi, Bhopal, Agra, Greater Noida, Patna, Tirupati, Pune, Kolkata, Noida and Jind) increase in CO levels during 2020 in comparison to 2019 was observed. Reduction in CO levels may be attributed to the restrictions imposed on transportation facilities during the lockdown period in 2020.

$\mathrm{SO}_{2}$ also showed a mixed variation with reduction in most of the cities (range 3-71\%; overall mean reduction 40\%) and increase at some sites (Hyderabad, Kanpur, Varanasi, Jorapokhar, Thiruvananthapuram, Mumbai, Bengaluru, Ujjain, Gaya, Lucknow, Agra, Bhopal and Jind). In India, $82 \%$ of total $\mathrm{SO}_{2}$ emission originates from the industrial sector and thermal power plants (Purohit et al., 2019), however during the lockdown period in 2020 no restrictions were enforced on thermal power plants. Therefore, a decreasing trend in
$\mathrm{SO}_{2}$ levels in all cities was not observed.

Similar to the present study reduction in $\mathrm{PM}_{10}, \mathrm{PM}_{2.5}$, $\mathrm{NO}_{2}, \mathrm{CO}$ and $\mathrm{SO}_{2}$ levels and a significant enhancement in $\mathrm{O}_{3}$ is observed at Iran, China, Kazakhstan, Singapore, Morocco, Brazil, Malaysia and Spain (Table 2) (Broomandi et al., 2020; Chen et al., 2020; Kerimray et al., 2020; Li and Tartarini, 2020; Otmani et al., 2020; Siciliano et al., 2020; Suhaimi et al., 2020; Tobias et al., 2020).

\section{Ghaziabad: World's Most Polluted City}

According to annual $\mathrm{PM}_{2.5}$ levels, Ghaziabad (annual $\mathrm{PM}_{2.5}$ mean $110.2 \mu \mathrm{g} \mathrm{m}^{-3}$ ) was found to be the world's most polluted city in 2019 (IQAir Report, 2019), therefore an indepth analysis of the impact of lockdown measures on pollutants levels was carried out there (Fig. 4). Ghaziabad is an industrial hub of India and comes in the part of National Capital Region (NCR) of Delhi. During lockdown period in 2020, average levels of $\mathrm{PM}_{10}(57 \%), \mathrm{PM}_{2.5}(48 \%), \mathrm{CO}(41 \%)$, $\mathrm{SO}_{2}(46 \%), \mathrm{O}_{3}(6 \%)$ and $\mathrm{NO}_{2}(59 \%)$ showed reduction in comparison to 2019 (Table 3). A significant difference in all pollutants levels during the lockdown period in 2019 and 2020 at $\mathrm{p}<0.05$ was observed. 
The time series plot of $\mathrm{PM}_{10}, \mathrm{PM}_{2.5}, \mathrm{CO}$ and $\mathrm{NO}_{2}$ was similar in I period ( $1^{\text {st }}$ February-2 $23^{\text {rd }}$ March) in both years while $\mathrm{O}_{3}$ showed higher values in 2020 as compared to 2019 . $\mathrm{SO}_{2}$ values in 2020 were comparatively lower than 2019 in I period. With the implementation of lockdown measures from $24^{\text {th }}$ March 2020, a sudden drop in all pollutants levels was observed. During II period ( $24^{\text {th }}$ March-31 ${ }^{\text {st }}$ May), $\mathrm{PM}_{10}$, $\mathrm{PM}_{2.5}, \mathrm{CO}$ and $\mathrm{NO}_{2}$ levels in 2020 were lower than 2019 however, $\mathrm{O}_{3}$ and $\mathrm{SO}_{2}$ showed some comparable values.

Fig. 5 show the average diurnal patterns of $\mathrm{PM}_{10}, \mathrm{PM}_{2.5}$, $\mathrm{O}_{3}, \mathrm{CO}, \mathrm{NO}_{2}$ and $\mathrm{SO}_{2}$ before ( $1^{\text {st }}$ February-23 $3^{\text {rd }}$ March) and during lockdown period ( $24^{\text {th }}$ March-31 $1^{\text {st }}$ May) in 2019 and

Table 2. Percentage change in air pollutants levels in other countries during their lockdown period. - denotes reduction and + denotes increase in pollutant level.

\begin{tabular}{|c|c|c|c|}
\hline City, Country & Study period & Percentage change & Reference \\
\hline Tehran, Iran & $\begin{array}{l}21^{\text {st }} \text { March-21 April 2019- } \\
2020\end{array}$ & $\begin{array}{l}\mathrm{PM}_{10}-11 \% ; \mathrm{PM}_{2.5}+10 \% ; \mathrm{NO}_{2}-13 \% \\
\mathrm{CO}-13 \% ; \mathrm{SO}_{2}-12 \% ; \mathrm{O}_{3}+3 \%\end{array}$ & $\begin{array}{l}\text { Broomandi et al. } \\
\text { (2020) }\end{array}$ \\
\hline $\begin{array}{l}\text { China } \\
\text { (366 urban areas) }\end{array}$ & January-April 2017-2020 & $\begin{array}{l}\mathrm{PM}_{10}-15 \% ; \mathrm{PM}_{2.5}-14 \% ; \mathrm{NO}_{2}-16 \% \\
\mathrm{CO}-12 \% ; \mathrm{SO}_{2}-12 \% ; \mathrm{O}_{3}+9 \%\end{array}$ & Chen et al. (2020) \\
\hline Almaty, Kazakhstan & $\begin{array}{l}19^{\text {th }} \text { March-1 } 14^{\text {th }} \text { April 2018- } \\
2020\end{array}$ & $\begin{array}{l}\mathrm{PM}_{2.5}-21 \% ; \mathrm{NO}_{2}-35 \% ; \mathrm{CO}-49 \% \\
\mathrm{SO}_{2}+7 \% ; \mathrm{O}_{3}+15 \%\end{array}$ & $\begin{array}{l}\text { Kerimray et al. } \\
\text { (2020) }\end{array}$ \\
\hline $\begin{array}{l}\text { Singapore } \\
\text { (64 stations) }\end{array}$ & $\begin{array}{l}7^{\text {th }} \text { April- } 11^{\text {th }} \text { May 2016- } \\
2020\end{array}$ & $\begin{array}{l}\mathrm{PM}_{10}-23 \% ; \mathrm{PM}_{2.5}-29 \% ; \mathrm{NO}_{2}-54 \% \\
\mathrm{CO}-6 \% ; \mathrm{SO}_{2}-52 \% ; \mathrm{O}_{3}+18 \%\end{array}$ & $\begin{array}{l}\text { Li and Tartarini, } \\
(2020)\end{array}$ \\
\hline Sale, Morocco & $11^{\text {th }}$ March-2 $2^{\text {nd }}$ April 2020 & $\mathrm{PM}_{10}-75 \% ; \mathrm{NO}_{2}-96 \% ; \mathrm{SO}_{2}-49 \%$ & $\begin{array}{l}\text { Otmani et al. } \\
(2020)\end{array}$ \\
\hline Iraja and Bangu, Brazil & $1^{\text {st }}$ March-16 $6^{\text {th }}$ April 2020 & $\mathrm{O}_{3}+12.9,+6.3 \%, \mathrm{NO}_{\mathrm{x}}-46.1,-24.4 \%$ & $\begin{array}{l}\text { Siciliano et al. } \\
(2020)\end{array}$ \\
\hline $\begin{array}{l}\text { Kuala Lumpur (Klang } \\
\text { Valley), Malaysia }\end{array}$ & $\begin{array}{l}11^{\text {th }} \text { March-2 } 1^{\text {st }} \text { April 2018- } \\
2020\end{array}$ & $\begin{array}{l}\mathrm{PM}_{2.5}-17 \text { to }-36 \% ; \mathrm{NO}_{2}-49 \text { to }-68 \% \\
\mathrm{CO}-21 \text { to }-48 \% ; \mathrm{SO}_{2}-6 \text { to }-26 \%\end{array}$ & $\begin{array}{l}\text { Suhaimi et al. } \\
(2020)\end{array}$ \\
\hline Barcelona, Spain & $\begin{array}{l}16^{\text {th }} \text { February- } 30^{\text {th }} \text { March } \\
2020\end{array}$ & $\begin{array}{l}\mathrm{PM}_{10}-28 \text { to }-31 \% ; \mathrm{NO}_{2}-47 \text { to }-51 \% \\
\mathrm{SO}_{2}-19 \text { to }+2 \% ; \mathrm{O}_{3}+28 \text { to }+58 \%\end{array}$ & $\begin{array}{l}\text { Tobias et al. } \\
(2020)\end{array}$ \\
\hline
\end{tabular}

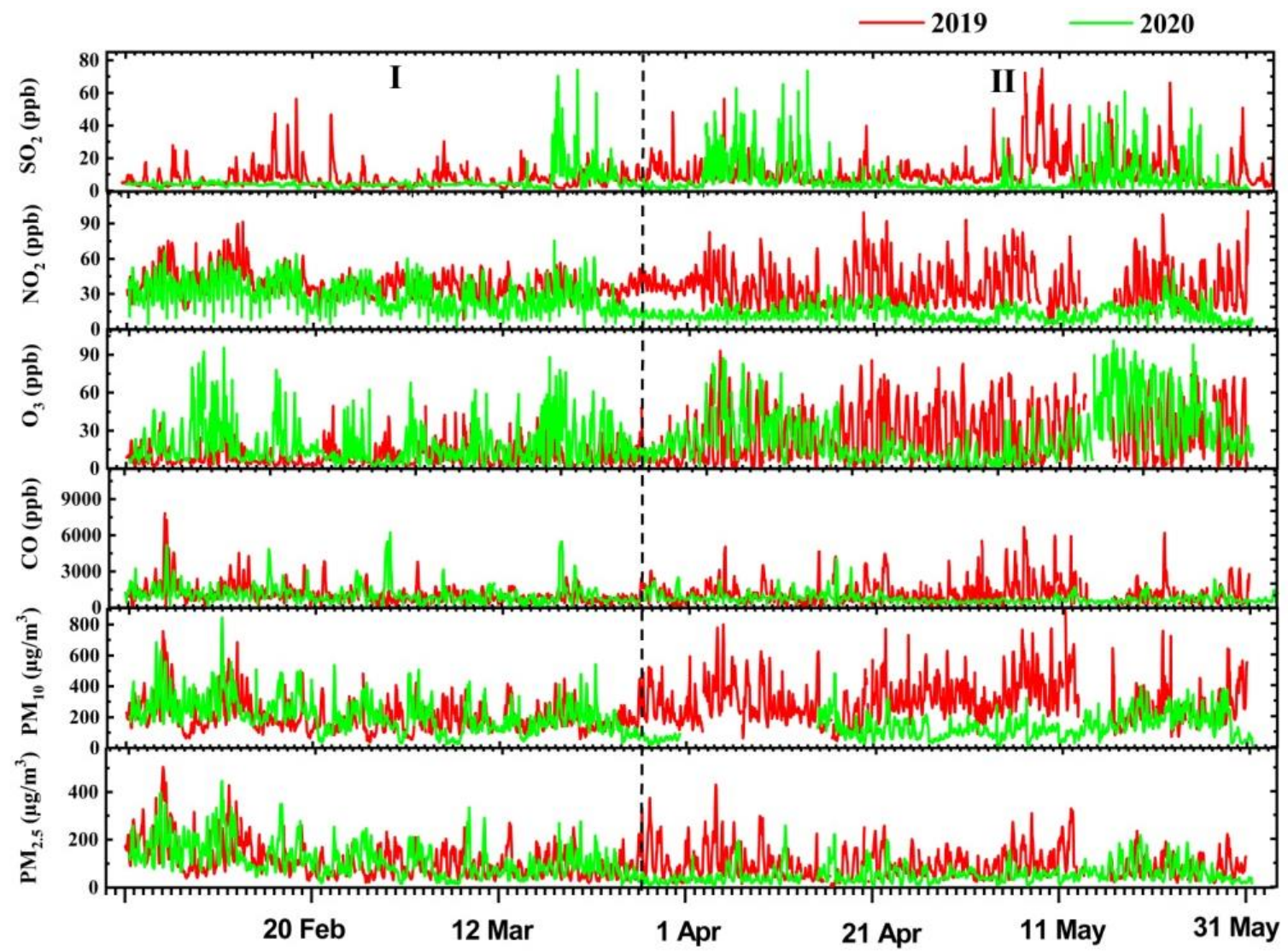

Fig. 4. Time series of hourly average $\mathrm{PM}_{10}, \mathrm{PM}_{2.5}, \mathrm{CO}, \mathrm{O}_{3}, \mathrm{NO}_{2}$ and $\mathrm{SO}_{2}$ levels during $1^{\text {st }}$ February-31 ${ }^{\text {st }}$ May 2019 and 2020 in Ghaziabad (dotted line show starting of lockdown period). 
Table 3. Mean concentrations of $\mathrm{PM}_{10}, \mathrm{PM}_{2.5}, \mathrm{CO}, \mathrm{O}_{3}, \mathrm{NO}_{2}$ and $\mathrm{SO}_{2}$ before ( $1^{\text {st }}$ February-23 ${ }^{\text {rd }}$ March) and during lockdown period ( $24^{\text {th }}$ March-31 ${ }^{\text {st }}$ May) in 2019 and 2020 in Ghaziabad.

\begin{tabular}{lllll}
\hline $\begin{array}{l}\text { Pollutant } \\
\text { unit) }\end{array}$ & $\begin{array}{l}2019 \mathrm{I} \\
\left(1^{\text {st }} \mathrm{Feb}-23^{\text {rd }} M a r 2019\right)\end{array}$ & $\begin{array}{l}2019 \mathrm{II} \\
\left(24^{\text {th }} \mathrm{Mar}-31^{\text {st }} \text { May } 2019\right)\end{array}$ & $\begin{array}{l}2020 \mathrm{I} \\
\left(1^{\text {st }} \mathrm{Feb}-23^{\text {rd }} \text { Mar 2020) }\right.\end{array}$ & $\begin{array}{l}2020 \mathrm{II} \\
\left(24^{\text {th }} \mathrm{Mar}^{-31} 1^{\text {st }} \mathrm{May} 2020\right)\end{array}$ \\
\hline $\mathrm{PM}_{10}\left(\mu \mathrm{g} \mathrm{m}^{-3}\right)$ & $205.4 \pm 104.4$ & $297.1 \pm 135.1$ & $210.9 \pm 112.9$ & $128.1 \pm 76.3$ \\
$\mathrm{PM}_{2.5}\left(\mu \mathrm{g} \mathrm{m}^{-3}\right)$ & $117.7 \pm 73.7$ & $97.1 \pm 61.1$ & $113.9 \pm 71.7$ & $50.5 \pm 37.2$ \\
$\mathrm{CO}(\mathrm{ppb})$ & $1146.8 \pm 785.2$ & $1176.2 \pm 932.4$ & $1068.9 \pm 739.9$ & $695.4 \pm 278.4$ \\
$\mathrm{O}_{3}(\mathrm{ppb})$ & $9.8 \pm 7.7$ & $25.5 \pm 20.8$ & $17.9 \pm 15.8$ & $23.9 \pm 19.8$ \\
$\mathrm{NO}_{2}(\mathrm{ppb})$ & $37.9 \pm 11.2$ & $36.3 \pm 16.2$ & $31.6 \pm 12.4$ & $14.7 \pm 6.4$ \\
$\mathrm{SO}_{2}(\mathrm{ppb})$ & $8.2 \pm 6.2$ & $12.5 \pm 10.7$ & $5.2 \pm 6$ & $6.7 \pm 8.7$ \\
\hline
\end{tabular}
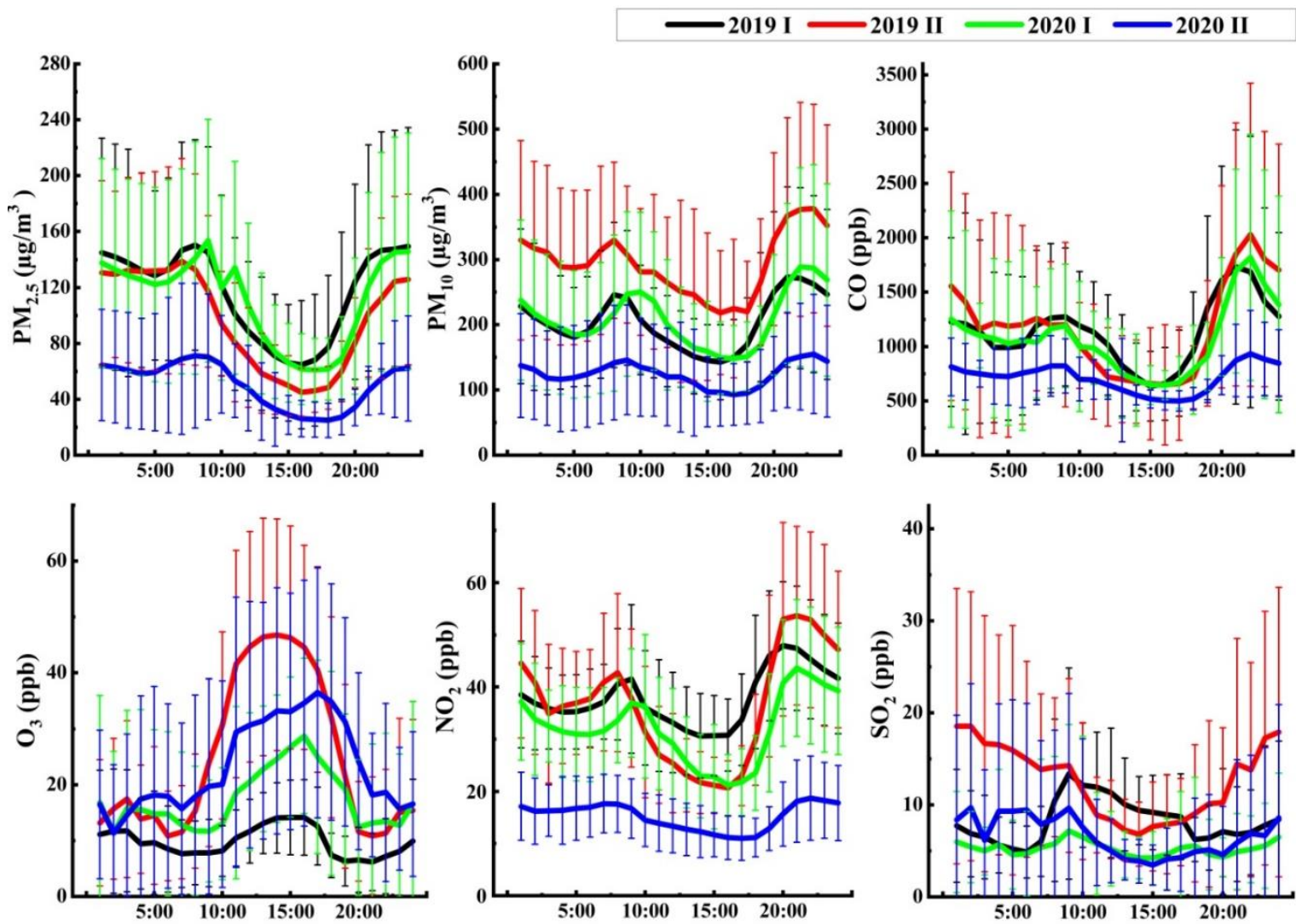

Fig. 5. Average diurnal variation of $\mathrm{PM}_{10}, \mathrm{PM}_{2.5}, \mathrm{CO}, \mathrm{O}_{3}, \mathrm{NO}_{2}$ and $\mathrm{SO}_{2}$ during $1^{\text {st }}$ February-23 ${ }^{\text {rd }}$ March (I) and $24^{\text {th }} \mathrm{March}-$ $31^{\text {st }}$ May (II) in 2019 and 2020 in Ghaziabad.

2020 at Ghaziabad. The diurnal patterns of $\mathrm{PM}_{10}, \mathrm{PM}_{2.5}, \mathrm{CO}$ and $\mathrm{NO}_{2}$ were characterized by a bimodal pattern with morning and evening peaks. The morning peak of these pollutants was observed at around 07:00-10:00 $\mathrm{h}$ and the evening peak at around 22:00 h. These peaks correspond to peak traffic emission hours. The diurnal pattern of ozone was characterized by minimum value in early morning $(07: 00 \mathrm{~h})$ and maximum value during afternoon $(\sim 14: 00 \mathrm{~h})$ due to photochemical formation.

On comparing the diurnal patterns of $\mathrm{PM}_{10}, \mathrm{PM}_{2.5}, \mathrm{CO}$ and $\mathrm{NO}_{2}$ during I period ( $1^{\text {st }}$ February-23 ${ }^{\text {rd }}$ March) in 2019 and 2020, similar patterns of $\mathrm{PM}_{10}, \mathrm{PM}_{2.5}$ and $\mathrm{CO}$ were observed however, $\mathrm{NO}_{2}$ showed comparatively lower values in 2020. Maximum difference observed in $\mathrm{PM}_{10}, \mathrm{PM}_{2.5}, \mathrm{CO}$ and $\mathrm{NO}_{2}$ diurnal values was $49.1 \mu \mathrm{g} \mathrm{m}^{-3}, 31.7 \mu \mathrm{g} \mathrm{m}^{-3}, 446.4 \mathrm{ppb}$ and $17.4 \mathrm{ppb}$, respectively. During the II period $\left(24^{\text {th }}\right.$
March-31 $1^{\text {st }}$ May), a very large variation in values of $\mathrm{PM}_{10}$, $\mathrm{PM}_{2.5}, \mathrm{CO}$ and $\mathrm{NO}_{2}$ values was observed. $\mathrm{PM}_{10}, \mathrm{PM}_{2.5}, \mathrm{CO}$ and $\mathrm{NO}_{2}$ diurnal values were $225.8 \mu \mathrm{g} \mathrm{m}^{-3}, 69.5 \mu \mathrm{g} \mathrm{m}^{-3}$, $1094.6 \mathrm{ppb}$ and $37.3 \mathrm{ppb}$, respectively lower in 2020 (during the lockdown period) than 2019. Another significant difference in the diurnal pattern of $\mathrm{PM}_{10}, \mathrm{PM}_{2.5}, \mathrm{CO}$ and $\mathrm{NO}_{2}$ during II period was the reduction in the amplitude of the pattern. The bimodal pattern of these pollutants was less distinct in 2020 II period as compared to other periods. The amplitudes of $\mathrm{PM}_{10}, \mathrm{PM}_{2.5}, \mathrm{CO}$ and $\mathrm{NO}_{2}$ were 61, 50, 68 and $77 \%$, respectively lower in II period in 2020 as compared to 2019. This may be attributed to restrictions imposed on transportation as vehicular emission is an important factor responsible for the bimodal pattern of these pollutants. On the other hand, secondary pollutant $\mathrm{O}_{3}$ showed higher variation in 2020 during I period and similar pattern in both years 
during II period. The diurnal pattern of $\mathrm{O}_{3}$ depends on the rate of photochemical generation, meteorological parameters: temperature, solar radiation, relative humidity, wind speed, wind direction, planetary boundary layer height and rate of deposition (Kumari et al., 2020). Averaged diurnal variation of $\mathrm{SO}_{2}$ does not show a distinct pattern. Higher diurnal values of $\mathrm{SO}_{2}$ in 2019 during both periods than 2020 were observed.

Patiala: City with Maximum Reduction in Pollution Level

In the present study, Patiala city showed maximum reduction in pollutants levels during the lockdown period in 2020, therefore a detailed analysis of pollutants level was also carried out at Patiala. Patiala is an agriculture-based city situated in the northern Indo-Gangetic Plain. During the lockdown period in 2020, all pollutants showed statistical significant reduction. Average levels of $\mathrm{PM}_{10}(58 \%)$, $\mathrm{PM}_{2.5}(57 \%), \mathrm{CO}(61 \%), \mathrm{SO}_{2}(13 \%)$ and $\mathrm{NO}_{2}(79 \%)$ showed reduction in lockdown period in 2020 (II) however, $\mathrm{O}_{3}$ showed an increase by $2 \%$ in comparison to 2019 (II) (Table 4). Mean pollutants levels at Patiala were comparatively lower than Ghaziabad during the study period however, comparatively higher reduction during the lockdown period was observed at Patiala.

Hourly average $\mathrm{PM}_{10}, \mathrm{PM}_{2.5}, \mathrm{CO}, \mathrm{O}_{3}, \mathrm{NO}_{2}$ and $\mathrm{SO}_{2}$ levels from $1^{\text {st }}$ February-31 ${ }^{\text {st }}$ May in 2019 and 2020 were compared for Patiala city (Fig. 6). During I period, comparative levels of $\mathrm{PM}_{2.5}, \mathrm{PM}_{10}, \mathrm{O}_{3}$ and $\mathrm{SO}_{2}$ were observed in both the years however, $\mathrm{NO}_{2}$ levels were low in 2020. With the implementation of lockdown measures, pollutants showed

Table 4. Mean concentrations of $\mathrm{PM}_{10}, \mathrm{PM}_{2.5}, \mathrm{CO}, \mathrm{O}_{3}, \mathrm{NO}_{2}$ and $\mathrm{SO}_{2}$ before ( $1^{\text {st }}$ February-23 $3^{\text {rd }}$ March) and during lockdown period ( $24^{\text {th }}$ March-31 ${ }^{\text {st }}$ May) in 2019 and 2020 in Patiala.

\begin{tabular}{lllll}
\hline $\begin{array}{l}\text { Pollutant } \\
\text { (unit) }\end{array}$ & $\begin{array}{l}2019 \mathrm{I} \\
\left(1^{\text {st }} \mathrm{Feb}-23^{\text {rd }} \text { Mar 2019) }\right)\end{array}$ & $\begin{array}{l}2019 \mathrm{II} \\
\left(24^{\text {th }} \mathrm{Mar}-31^{\text {st }} \text { May } 2019\right)\end{array}$ & $\begin{array}{l}2020 \mathrm{I} \\
\left(1^{\text {st }} \mathrm{Feb}-23^{\text {rd }} \text { Mar 2020 }\right)\end{array}$ & $\begin{array}{l}2020 \mathrm{II} \\
\left(24^{\text {th }} \mathrm{Mar}^{-3} 1^{\text {st }} \mathrm{May} 2020\right)\end{array}$ \\
\hline $\mathrm{PM}_{10}\left(\mu \mathrm{g} \mathrm{m}^{-3}\right)$ & $111.3 \pm 51.5$ & $153 \pm 84.3$ & $81.8 \pm 33.6$ & $64 \pm 41.7$ \\
$\mathrm{PM}_{2.5}\left(\mu \mathrm{g} \mathrm{m}^{-3}\right)$ & $40.1 \pm 20.5$ & $56.8 \pm 24.3$ & $37.2 \pm 17.3$ & $24.6 \pm 15.2$ \\
$\mathrm{CO}(\mathrm{ppb})$ & $557.8 \pm 207.4$ & $992 \pm 518.8$ & $679.6 \pm 128.1$ & $382.9 \pm 57.9$ \\
$\mathrm{O}_{3}(\mathrm{ppb})$ & $5.4 \pm 3.9$ & $10.1 \pm 6.4$ & $6.3 \pm 4.6$ & $10.3 \pm 6.7$ \\
$\mathrm{NO}_{2}(\mathrm{ppb})$ & $18.5 \pm 11.3$ & $22 \pm 17.8$ & $3.6 \pm 1.5$ & $4.6 \pm 2.8$ \\
$\mathrm{SO}_{2}(\mathrm{ppb})$ & $1.5 \pm 0.8$ & $3.1 \pm 1.9$ & $2.7 \pm 1.8$ & $2.7 \pm 2.2$ \\
\hline
\end{tabular}

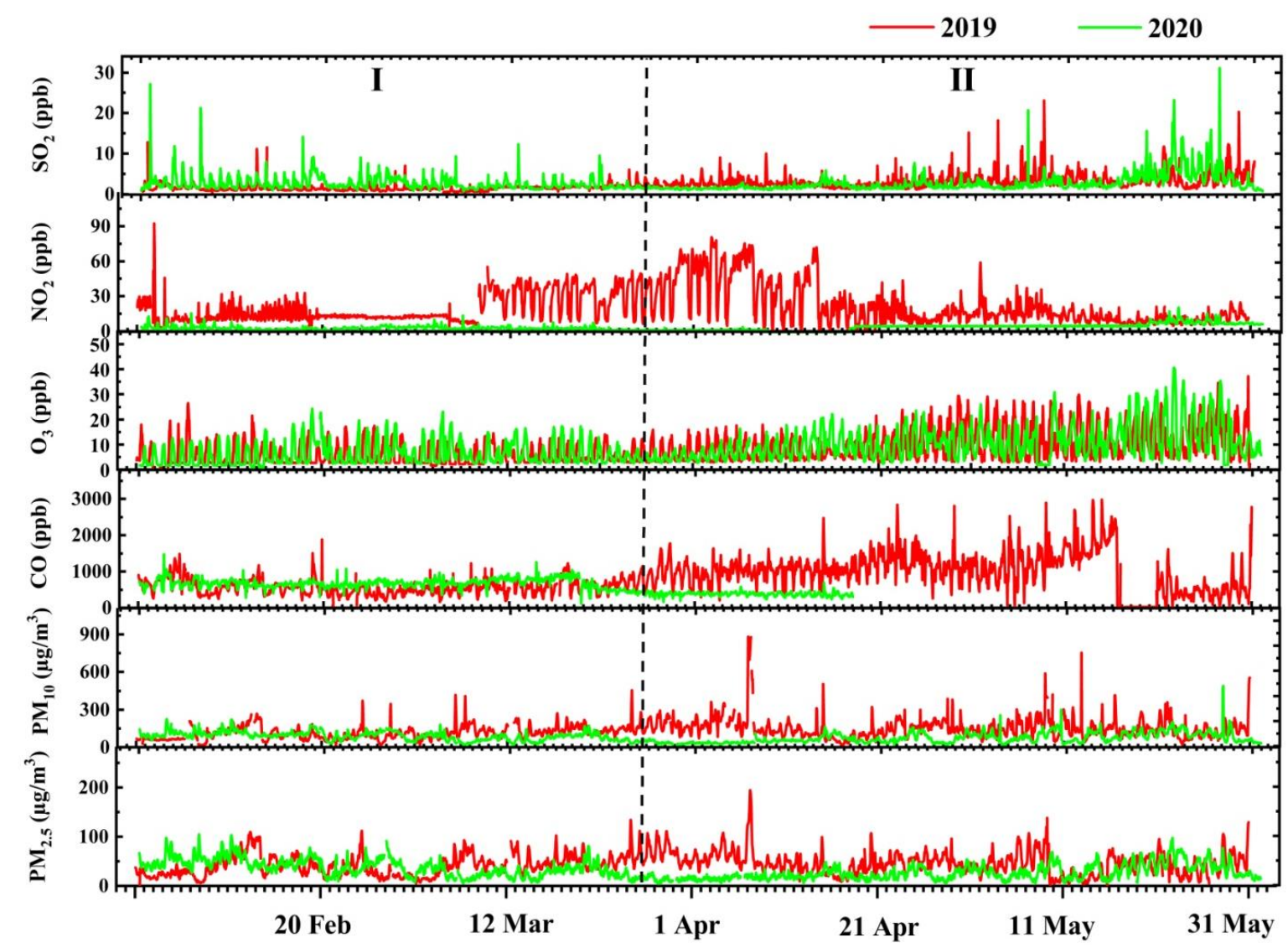

Fig. 6. Time series of hourly average $\mathrm{PM}_{10}, \mathrm{PM}_{2.5}, \mathrm{CO}, \mathrm{O}_{3}, \mathrm{NO}_{2}$ and $\mathrm{SO}_{2}$ levels during $1^{\text {st }}$ February- $31^{\text {st }}$ May 2019 and 2020 in Patiala (dotted line show starting of lockdown period). 

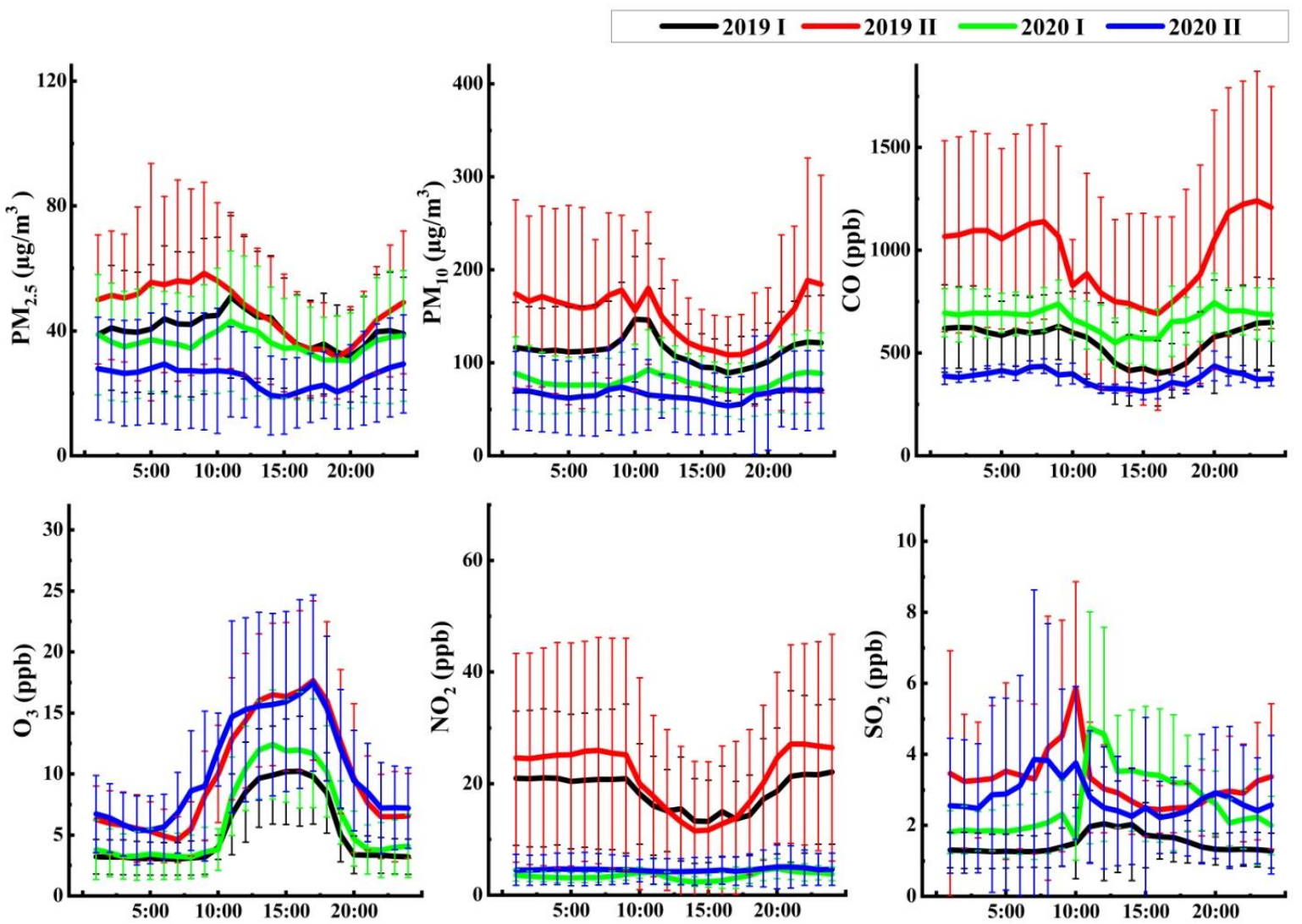

Fig. 7. Average diurnal variation of $\mathrm{PM}_{10}, \mathrm{PM}_{2.5}, \mathrm{CO}, \mathrm{O}_{3}, \mathrm{NO}_{2}$ and $\mathrm{SO}_{2}$ during $1^{\text {st }}$ February-23 $3^{\text {rd }}$ March (I) and $24^{\text {th }} \mathrm{March}-$ $31^{\text {st }}$ May (II) in 2019 and 2020 in Patiala.

sudden reduction in levels (on $24^{\text {th }}$ March 2020). $\mathrm{PM}_{2.5}$, $\mathrm{PM}_{10}, \mathrm{CO}, \mathrm{NO}_{2}$ and $\mathrm{SO}_{2}$ levels were lower in $2020 \mathrm{II}$ period as compared to 2019 II period whereas $\mathrm{O}_{3}$ levels were comparable. A similar variation was observed at Ghaziabad.

Similar to Ghaziabad, bimodal diurnal patterns of $\mathrm{PM}_{10}$, $\mathrm{PM}_{2.5}, \mathrm{CO}$ and $\mathrm{NO}_{2}$ were observed in Patiala (Fig. 7). $\mathrm{O}_{3}$ showed a unimodal diurnal pattern however, no distinct diurnal pattern of $\mathrm{SO}_{2}$ was observed. During I period, diurnal patterns of $\mathrm{PM}_{10}, \mathrm{PM}_{2.5}, \mathrm{O}_{3}$ and $\mathrm{CO}$ were comparable. Maximum deviation observed in $\mathrm{PM}_{10}, \mathrm{PM}_{2.5}, \mathrm{CO}, \mathrm{O}_{3}, \mathrm{NO}_{2}$ and $\mathrm{SO}_{2}$ diurnal values was $53.1 \mu \mathrm{g} \mathrm{m}^{-3}, 8.2 \mu \mathrm{g} \mathrm{m}^{-3}, 239.6 \mathrm{ppb}$, $2.5 \mathrm{ppb}, 17.8 \mathrm{ppb}$ and $2.8 \mathrm{ppb}$, respectively. During II period, diurnal patterns were comparatively lower in 2020 except for $\mathrm{O}_{3}$. Maximum reduction observed in the diurnal values of $\mathrm{PM}_{10}, \mathrm{PM}_{2.5}, \mathrm{CO}, \mathrm{O}_{3}, \mathrm{NO}_{2}$ and $\mathrm{SO}_{2}$ was $118.8 \mu \mathrm{g} \mathrm{m}^{-3}$, $31.4 \mu \mathrm{g} \mathrm{m}^{-3}, 869.1 \mathrm{ppb}, 3.1 \mathrm{ppb}, 21.9 \mathrm{ppb}$ and $2.1 \mathrm{ppb}$, respectively. The amplitude of the pattern was also lower as compared to 2019 II period and no clear bimodal patterns of $\mathrm{PM}_{10}, \mathrm{PM}_{2.5}, \mathrm{CO}$ and $\mathrm{NO}_{2}$ were observed. Amplitudes of $\mathrm{PM}_{10}, \mathrm{PM}_{2.5}, \mathrm{CO}$ and $\mathrm{NO}_{2}$ were $75,61,78$ and $94 \%$ lower, respectively in 2020 II period. This may be attributed by restrictions imposed on vehicular activities.

\section{CONCLUSION}

Implementation of the lockdown measures as a preventive step to control the spread of COVID-19 resulted in restrictions on transportation and industrial activities. As a result air pollution levels dropped significantly. The present study provides detail of the impact of lockdown on air pollution in 39 different cities of India. The primary pollutant concentrations $\left(\mathrm{PM}_{10}, \mathrm{PM}_{2.5}, \mathrm{CO}\right.$ and $\left.\mathrm{NO}_{2}\right)$ showed decreased levels in all cities however, secondary pollutant $\left(\mathrm{O}_{3}\right)$ showed both increasing and decreasing trends. Overall 44, 38, 28, 42 and $40 \%$ reduction was observed in $\mathrm{PM}_{10}, \mathrm{PM}_{2.5}, \mathrm{CO}, \mathrm{NO}_{2}$ and $\mathrm{SO}_{2}$ levels, respectively during the lockdown period in 2020 as compared to 2019. Reduced primary pollutants were mainly attributed to restrictions imposed on transportation and industrial activities as these activities are their primary sources. Increase in $\mathrm{O}_{3}$ levels may be due to reduced $\mathrm{NO}$ titration. Though the reduction observed in the pollutants levels during the lockdown period is expected to be short-lived, it provides evidence that widespread implementation of air pollution measures can result in immediate air quality benefits. Therefore, in worst air quality scenario restrictions on vehicles and industries can help in improving the air quality.

\section{ACKNOWLEDGEMENT}

The authors are thankful to the Director, Dayalbagh Educational Institute, Agra, and the Head, Department of Chemistry, for the necessary help. Authors are also thankful to the Central Pollution Control Board, India for data. Ms. Sonal Kumari is thankful to ISRO-GBP for providing fellowship (SRF) under ATCTM Project. 


\section{REFERENCES}

Balakrishnan, K., Dey, S., Gupta, T., Dhaliwal, R.S., Brauer, M., Cohen, A.J., Stanaway, J.D., Beig, G., Joshi, T.K., Aggarwal, A.N. and Sabde, Y. (2019). The impact of air pollution on deaths, disease burden, and life expectancy across the states of India: The Global Burden of Disease Study 2017. Lancet Planet. Health 3: 26-39. https://doi.org/10.1016/S2542-5196(18)30261-4

Bashir, M.F., Ma, B., Komal, B., Bashir, M.A., Tan, D. and Bashir, M. (2020). Correlation between climate indicators and COVID-19 pandemic in New York, USA. Sci. Total Environ. 728: 138835. https://doi.org/10.1016/j.scitotenv. 2020.138835

Broomandi, P., Karaca, F., Nikfal, A., Jahanbakhshi, A., Tamjidi, M. and Kim, J.R. (2020). Impact of COVID-19 event on the air quality in Iran. Aerosol Air Qual. Res. 20: 1793-1804. https://doi.org/10.4209/aaqr.2020.05.0205

Chauhan, A. and Singh, R.P. (2020). Decline in $\mathrm{PM}_{2.5}$ concentrations over major cities around the world associated with COVID-19. Environ. Res. 187: 109634. https://doi.org/10.1016/j.envres.2020.109634

Chen, Q.X., Huang, C.L., Yuan, Y. and Tan, H.P. (2020). Influence of COVID-19 event on air quality and their association in Mainland China. Aerosol Air Qual. Res. 20: 1541-1551. https://doi.org/10.4209/aaqr.2020.05.0224

Chowdhury, S. and Dey, S., (2016). Cause-specific premature death from ambient $\mathrm{PM}_{2.5}$ exposure in India: Estimate adjusted for baseline mortality. Environ. Int. 91: 283-290. https://doi.org/10.1016/j.envint.2016.03.004

Copernicus Atmosphere Monitoring Service (CAMS) (2020). Amid Coronavirus outbreak: Copernicus monitors reduction of particulate matter $\left(\mathrm{PM}_{2.5}\right)$ over China. https://atmosphe re.copernicus.eu/amid-coronavirus-outbreak-copernicusmonitors-reduction-particulate-matter-pm25-over-china

Gupta, S., Raghuwanshi, G.S. and Chanda, A. (2020). Effect of weather on COVID-19 spread in the US: A prediction model for India in 2020. Sci. Total Environ. 728: 138860. https://doi.org/10.1016/j.scitotenv.2020.138860

Holloway, T., Levy, H. and Kasibhatla, P. (2000). Global distribution of carbon monoxide. J. Geophys. Res. 105: 12123-12147. https://doi.org/10.1029/1999JD901173

International Energy Agency (IEA) (2016). World energy outlook special report: Energy and air pollution. International Energy Agency, Paris, France.

IQAir (2019). World Air Quality Report 2019: Region and city $\mathrm{PM}_{2.5}$ ranking. https://www.iqair.com/world-mostpolluted-cities

Jain, S. and Sharma, T. (2020). Social and travel lockdown impact considering coronavirus disease (COVID-19) on air quality in megacities of India: Present benefits, future challenges and way forward. Aerosol Air Qual. Res. 20: 1222-1236. https://doi.org/10.4209/aaqr.2020.04.0171

Kerimray, A., Baimatova, N., Ibragimova, O.P., Bukenov, B., Kenessov, B., Plotitsyn, P. and Karaca, F. (2020). Assessing air quality changes in large cities during COVID-19 lockdowns: The impacts of traffic-free urban conditions in Almaty, Kazakhstan. Sci. Total Environ. 728: 139179. https://doi.org/10.1016/j.scitotenv.2020.139179
Klimont, Z., Kupiainen, K., Heyes, C., Purohit, P., Cofala, J., Rafaj, P., Borken-Kleefeld, J. and Schöpp, W. (2017). Global anthropogenic emissions of particulate matter including black carbon. Atmos. Chem. Phys. 17: 86818723. https://doi.org/10.5194/acp-17-8681-2017

Kotnala, G., Mandal, T.K., Sharma, S.K. and Kotnala, R.K. (2020). Emergence of blue sky over Delhi due to coronavirus disease (COVID-19) lockdown implications. Aerosol Sci. Eng. 4: 228-238. https://doi.org/10.1007/s4 1810-020-00062-6

Krotkov, N.A., Lamsal, L.N., Celarier, E.A., Swartz, W.H., Marchenko, S.V., Bucsela, E.J., Chan, K.L., Wenig, M. and Zara, M. (2017). The version $3 \mathrm{OMI} \mathrm{NO}_{2}$ standard product. 10: 3133-3149. https://doi.org/10.5194/amt-103133-2017

Kumar, A. and Goyal, P. (2011). Forecasting of daily air quality index in Delhi. Sci. Total Environ. 409: 55175523. https://doi.org/10.1016/j.scitotenv.2011.08.069

Kumar, P., Hama, S., Omidvarborna, H., Sharma, A., Sahani, J., Abhijith, K.V., Debele, S.E., Zavala-Reyes, J.C., Barwise, Y. and Tiwari, A. (2020). Temporary reduction in fine particulate matter due to 'anthropogenic emissions switch-off' during COVID-19 lockdown in Indian cities. Sustain. Cities Soc. 62: 102382. https://doi.org/10.1016/j. scs.2020.102382

Kumar, S. (2020). Effect of meteorological parameters on spread of COVID-19 in India and air quality during lockdown. Sci. Total Environ. 745: 141021. https://doi.org/ 10.1016/j.scitotenv.2020.141021

Kumari, S., Verma, N., Lakhani, A., Tiwari, S. and Kandikonda, M.K. (2018). Tropospheric ozone enhancement during post-harvest crop-residue fires at two downwind sites of the Indo-Gangetic Plain. Environ. Sci. Pollut. Res. 25: 18879-18893. https://doi.org/10.1007/s1 1356-018-2034-y

Kumari, S., Lakhani, A. and Kumari, K.M. (2020). First observation-based study on surface $\mathrm{O}_{3}$ trend in IndoGangetic Plain: Assessment of its impact on crop yield. Chemosphere 255: 126972. https://doi.org/10.1016/j.che mosphere.2020.126972

Li, J. and Tartarini, F. (2020). Changes in air quality during the COVID-19 lockdown in Singapore and associations with human mobility trends. Aerosol Air Qual. Res. 20: 1748-1758. https://doi.org/10.4209/aaqr.2020.06.0303

Mahato, S., Pal, S. and Ghosh, K.G. (2020). Effect of lockdown amid COVID-19 pandemic on air quality of the megacity Delhi, India. Sci. Total Environ. 730: 139086. https://doi.org/10.1016/j.scitotenv.2020.139086

Méndez-Arriaga, F. (2020). The temperature and regional climate effects on communitarian COVID-19 contagion in Mexico throughout phase 1. Sci. Total Environ. 735: https://doi.org/10.1016/j.scitotenv.2020.139560139560

Menebo, M.M. (2020). Temperature and precipitation associate with Covid-19 new daily cases: A correlation study between weather and Covid-19 pandemic in Oslo, Norway. Sci. Total Environ. 737: 139659. https://doi.org/ 10.1016/j.scitotenv.2020.139659

Muhammad, S., Long, X. and Salman, M. (2020). COVID19 pandemic and environmental pollution: A blessing in 
disguise? Sci. Total Environ. 728: 138820. https://doi.org/10.1016/j.scitotenv.2020.138820

NAAQS, CPCB (2009). The gazette of India, ministry of environmental and forests notification. In: National Ambient Air Quality Standards 16

Navinya, C., Patidar, G. and Phuleria, H.C. (2020). Examining effects of the COVID-19 national lockdown on ambient air quality across urban India. Aerosol Air Qual. Res. 20: 1759-1771. https://doi.org/10.4209/aaqr.2 020.05.0256

Otmani, A., Benchrif, A., Tahri, M., Bounakhla, M., El Bouch, M. and Krombi, M.H. (2020). Impact of Covid-19 lockdown on $\mathrm{PM}_{10}, \mathrm{SO}_{2}$ and $\mathrm{NO}_{2}$ concentrations in Salé City (Morocco). Sci. Total Environ. 7358: 139541. https://doi.org/10.1016/j.scitotenv.2020.139541

Pani, S.K., Lin, N.H. and RavindraBabu, S. (2020). Association of COVID-19 pandemic with meteorological parameters over Singapore. Sci. Total Environ. 740: 140112. https://doi.org/10.1016/j.scitotenv.2020.140112

Purohit, P., Amann, M., Kiesewetter, G., Rafaj, P., Chaturvedi, V., Dholakia, H.H., Koti, P.N., Klimont, Z., Borken-Kleefeld, J., Gomez-Sanabria, A. and Schöpp, W. (2019). Mitigation pathways towards national ambient air quality standards in India. Environ. Int. 133: 105147. https://doi.org/10.1016/j.envint.2019.105147

Şahin, M. (2020). Impact of weather on COVID-19 pandemic in Turkey. Sci. Total Environ. 728: 138810. https://doi.org/10.1016/j.scitotenv.2020.138810

Sahu, S.K., Beig, G., Parkhi, N.S. (2012). Emerging pattern of anthropogenic $\mathrm{NO}_{\mathrm{x}}$ emission over Indian subcontinent during 1990s and 2000s. Atmos. Pollut. Res. 3: 262-269. https://doi.org/10.5094/APR.2012.021

Sharma, S., Chatani, S., Mahtta, R., Goel, A. and Kumar, A. (2016). Sensitivity analysis of ground level ozone in India using WRF-CMAQ models. Atmos. Environ. 131: 29-40. https://doi.org/10.1016/j.atmosenv.2016.01.036

Sharma, S., Zhang, M., Gao, J., Zhang, H. and Kota, S.H. (2020). Effect of restricted emissions during COVID-19 on air quality in India. Sci. Total Environ. 728: 138878. https://doi.org/10.1016/j.scitotenv.2020.138878

Shehzad, K., Sarfraz, M., and Shah, S.G.M. (2020). The impact of COVID-19 as a necessary evil on air pollution in India during the lockdown. Environ. Pollut. 266: 115080. https://doi.org/10.1016/j.envpol.2020.115080

Siciliano, B., Dantas, G., da Silva, C.M. and Arbilla, G. (2020). Increased ozone levels during the COVID-19 lockdown: Analysis for the city of Rio de Janeiro, Brazil. Sci. Total Environ. 737: 139765. https://doi.org/10.1016/ j.scitotenv.2020.139765

Singh, R.P. and Chauhan, A. (2020). Impact of lockdown on air quality in India during COVID-19 pandemic. Air Qual. Atmos. Health 13: 921-928. https://doi.org/10.100 7/s11869-020-00863-1

Srivastava, S., Kumar, A., Bauddh, K., Gautam, A.S. and Kumar, S. (2020). 21-Day Lockdown in India Dramatically Reduced Air Pollution Indices in Lucknow and New Delhi, India. Bull. Environ. Contam. Toxicol. 105: 9-17. https://doi.org/10.1007/s00128-020-02895-w

Suhaimi, N.F., Jalaludin, J. and Latif, M.T. (2020). Demystifying a possible relationship between COVID19, air quality and meteorological factors: Evidence from Kuala Lumpur, Malaysia. Aerosol and Air Qual. Res. 20: 1520-1529. https://doi.org/10.4209/aaqr.2020.05.0218

Tobías, A. and Molina, T. (2020). Is temperature reducing the transmission of COVID-19? Environ. Res. 186: 109553. https://doi.org/10.1016/j.envres.2020.109553

Tobías, A., Carnerero, C., Reche, C., Massagué, J., Via, M., Minguillón, M.C., Alastuey, A. and Querol, X. (2020). Changes in air quality during the lockdown in Barcelona (Spain) one month into the SARS-CoV-2 epidemic. Sci. Total Environ. 726: 138540. https://doi.org/10.1016/j.sci totenv.2020.138540

Tosepu, R., Gunawan, J., Effendy, D.S., Lestari, H., Bahar, H. and Asfian, P. (2020). Correlation between weather and Covid-19 pandemic in Jakarta, Indonesia. Sci. Total Environ. 725: 138436. https://doi.org/10.1016/j.scitotenv. 2020.138436

U.S. Environmental Protection Agency (U.S. EPA) (1999). Air quality index reporting; final rule. federal register, Part III, 40 CFR Part 58.

Venkataraman, C., Brauer, M., Tibrewal, K., Sadavarte, P., Ma, Q., Cohen, A., Chaliyakunnel, S., Frostad, J., Klimont, Z., Martin, R.V. and Millet, D.B. (2018). Source influence on emission pathways and ambient $\mathrm{PM}_{2.5}$ pollution over India (2015-2050). Atmos. Chem. Phys. 18: 8017-8039. https://doi.org/10.5194/acp-18-8017-2018

World Health Organization (WHO) (2020). WHO timeline COVID-19. https://www.who.int/news-room/detail/2704-2020-who-timeline---covid-19

Xu, K., Cui, K., Young, L.H., Hsieh, Y.K., Wang, Y.F., Zhang, J. and Wan, S. (2020). Impact of the COVID-19 event on air quality in central China. Aerosol Air Qual. Res. 20: 915-929. https://doi.org/10.4209/aaqr.2020.04. 0150

Yao, Y., Pan, J., Liu, Z., Meng, X., Wang, W., Kan, H. and Wang, W. (2020). No Association of COVID-19 transmission with temperature or UV radiation in Chinese cities. Euro. Respir. J. 2000517. https://doi.org/10.1183/1 3993003.00517-2020

Zambrano-Monserrate, M.A., Ruano, M.A. and SanchezAlcalde, L. (2020). Indirect effects of COVID-19 on the environment. Sci. Total Environ. 728: 138813. https://doi.org/10.1016/j.scitotenv.2020.138813

Zhu, Y., Jingu, X., Fengming, H. and Liqing. C. (2020). Association between short-term exposure to air pollution and COVID-19 infection: Evidence from China. Sci. Total Environ. 727: 138704. https://doi.org/10.1016/j.sci totenv.2020.138704

Received for review, May 26, 2020

Revised, September 25, 2020

Accepted, September 28, 2020 